\title{
BIOLOGI REPRODUKSI IKAN BETOK (Anabas testudineus) DI PAPARAN BANJIRAN LUBUK LAMPAM, KABUPATEN OGAN KOMERING ILIR
}

\author{
REPRODUCTIVE BIOLOGY OF CLIMBING PERCH (Anabas testudineus) \\ IN LUBUK LAMPAM FLOODPLAIN, OGAN KOMERING ILIR REGENCY
}

\author{
Eko Prianto ${ }^{1,3}$, Mohammad Mukhlis Kamal ${ }^{2}$, Ismudi Muchsin² ${ }^{2}$ dan Endi Setiadi Kartamihardja ${ }^{3}$ \\ ${ }^{1}$ Mahasiswa pada Program Doktor Mayor Pengelolaan Sumberdaya Perairan-IPB \\ ${ }^{2}$ Doses pada Fakultas Perikanan dan Ilmu Kelautan Institut Pertanian Bogor-IPB \\ ${ }^{3}$ Peneliti pada Pusat Penelitian Pengelolaan Perikanan dan Konservasi Sumberdaya Ikan \\ Teregistrasi I tanggal: 11 Juli 2014; Diterima setelah perbaikan tanggal: 05 Nopember 2014; \\ Disetujui terbit tanggal: 26 Nopember 2014 \\ Email:eko_pesisir@yahoo.com
}

\begin{abstract}
ABSTRAK
Ikan betok (Anabas testudineus) adalah salah satu jenis ikan ekonomis penting yang dihasilkan dari perairan paparan banjiran. Penelitian yang bertujuan untuk mengkaji beberapa aspek biologi reproduksi ikan betok di paparan banjiran Lubuk Lampam, Kabupaten Ogan Komering Ilir dilakukan pada bulan Nopember 2012Oktober 2013. Sampel ikan ditangkap setiap bulan menggunakan alat tangkap jaring dan bengkirai. Analisis data meliputi sebaran frekuensi ukuran panjang, nisbah kelamin, tingkat kematangan gonad, indeks kematangan gonad, ukuran pertamakali matang gonad, potensi reproduksi dan pola reproduksi. Jumlah sampel ikan betok yang diperoleh sebanyak 540 ekor, terdiri dari 187 ekor ikan jantan dan 353 ekor ikan betina, dengan kisaran panjang ikan betina antara 27-224 mm dan ikan jantan antara 48-243 mm. Rasio kelamin ikan jantan dan betina adalah $0,53: 1$. Tingkat kematangan gonad (TKG) ikan jantan dan betina yang paling banyak ditemui adalah TKG I dengan frekuensi tertinggi pada ukuran 116-132 mm dan 114-129 mm masing-masing berjumlah 34 dan 33 ekor. Perkembangan tingkat kematangan gonad ikan betok dipengaruhi oleh perubahan tinggi muka air secara musiman. Indek kematangan gonad ikan jantan pada TKG IV berkisar 1,3-15,0\% dan ikan betina berkisar antara $1,2-17,1 \%$. Ukuran pertama kali matang gonad ikan betina adalah pada panjang total $160 \mathrm{~mm}$ dan ikan jantan pada panjang total $177 \mathrm{~mm}$. Fekunditas ikan betok berkisar antara 224-182.736 butir dengan diameter telur berkisar antara 0,465-1,026 mm dengan pola pemijahan secara sebagian.
\end{abstract}

KATA KUNCI: Biologi reproduksi, ikan betok, Anabas testudineus, paparan banjiran, Lubuk Lampam

\begin{abstract}
Climbing perch, Anabas testudineus is a dominant commercial fish inhabit floodplain area of Lubuk Lampam, Ogan Komering Ilir Regency. A study aimed to investigate some aspects of the reproductive biology of climbing perch has been conducted at floodplain of Lubuk Lampam, Ogan Komering Ilir regency from November 2012 to October 2013. Fish sampling was conducted every month using nets and bamboo trap. The data analysis includes lenght frequency distribution, sex ratio, the gonado maturity, gonado somatic index, the size at first maturity, fecundity and reproductive patterns. Climbing perch sample amounted of 540 specimen compose of 187 males and 353 females, with the lenght frequency between 27-224 mm (female) and 48-243 mm (male). Sex ratio of the male and female of the climbing perch was $0,53: 1$. The gonado maturity of male and female are mostly at the first level with the highest frequency between 116-132 mm and 114-129 mm, equivalent to 34 and 33 specimen, respectively. The development of gonado maturity of climbing perch was influenced by seasonally of water level fluctuation. Gonado somatic index of maturity of male and female range 1.3-15.0\% and 1.2 $17.1 \%$, respectively. The size at the first maturity of the female was $160 \mathrm{~mm}$ lenght and of the male was $177 \mathrm{~mm}$ lenght. The fecundity ranges 224 to182,736 eggs with the egg diameter ranges 0.465-1.026 mm and the climbing perch was classified into partially spawner.
\end{abstract}

KEYWORDS: Reproductive biology, climbing perch, Anabas testudineus, floodplain, Lubuk Lampam

\section{PENDAHULUAN}

Ogan Komering Ilir (OKI) merupakan salah satu Kabupaten di Provinsi Sumatera Selatan yang wilayahnya didominasi oleh perairan paparan banjiran. Paparan Banjiran merupakan salah satu ekosistem perairan produktif bagi pengembangan perikanan tangkap. Puncak musim penangkapan ikan di perairan tipe paparan banjiran terjadi pada saat musim kemarau karena kebanyakan ikanikan terkonsentrasi pada tempat-tempat tertentu yang masih ada airnya. Ikan betok (Anabas testudineus) adalah salah satu ikan ekonomis penting yang dihasilkan dari perairan ini. 
Ikan betok merupakan ikan asli perairan umum daratan Indonesia yang distribusinya meliputi Asia Selatan dan Asia Tenggara, habitatnya meliputi sungai, kanal, danau, kolam, rawa-rawa dan sawah. Di Pulau Sumatera, Jawa dan Kalimantan ikan ini dapat ditemukan di rawa, sungai, danau dan selokan air (Bungas et al., 2013; Jacob, 2005; Thakur, 2004; Shinsuke et al., 2009). Ikan betok memiliki alat pernapasan tambahan (labyrinth) untuk membantu pengambilan oksigen dari udara (Akbar, 2012; Jacob, 2005; Shinsuke et al., 2009) dan juga mampu hidup pada perairan asam $(\mathrm{pH}<4)$ bahkan dapat hidup pada salinitas perairan hingga 11,5 permil (Khan et al., 1976).

Ikan betok dikenal dengan nama umum climbing perch, mempunyai tekstur daging yang lembut dan gurih sehingga digemari oleh masyarakat (Murjani, 2011). Permintaan ikan betok yang tinggi di masyarakat menjadikan ikan ini sebagai hasil tangkapan utama nelayan. Selama ini produksi ikan betok masih didominasi dari hasil tangkapan di alam sehingga intensitas penangkapan meningkat dan berakibat terhadap penurunan populasinya di kemudian hari (Ernawati et al., 2009; Murjani, 2011) ikan betok merupakan spesies yang terancam dan populasinya di alam terus menurun sebagai akibat dari tangkapan lebih, polusi (degradasi lingkungan) dan metode budidayanya yang belum berkembang pesat saat ini (Bungas et al., 2013).

Penelitian ini bertujuan untuk mengetahui beberapa aspek biologi reproduksi ikan betok di paparan banjiran Lubuk Lampam. Hasil penelitian ini diharapkan dapat menjadi informasi tambahan dalam upaya pengelolaan sumberdaya ikan betok agar dapat dimanfaatkan secara optimal dan berkelanjutan.

\section{METODE PENELITIAN}

\section{Waktu dan Lokasi Pengambilan Sampel}

Penelitian ini dilakukan di perairan paparan banjiran Lubuk Lampam Kabupaten Ogan Komering Ilir, Provinsi Sumatera Selatan (Gambar 1). Pengambilan sampel ikan dilakukan setiap bulan mulai bulan Nopember 2012Oktober 2013, yaitu pada saat permukaan air mulai naik mencapai tinggi maksimal hingga surut. Pengamatan tinggi muka air menggunakan papan ukur dilakukan oleh enumerator yang dilakukan setiap minggu. Sampel ikan dikumpulkan dari hasil tangkapan nelayan/enumerator dan hasil tangkapan percobaan dengan menggunakan alat tangkap jaring insang (gill net) dan bengkirai (traps). Ikan betok diukur panjang-beratnya dan selanjutnya dibedah untuk pengamatan tingkat kematangan gonad, indeks kematangan gonad dan fekunditas.

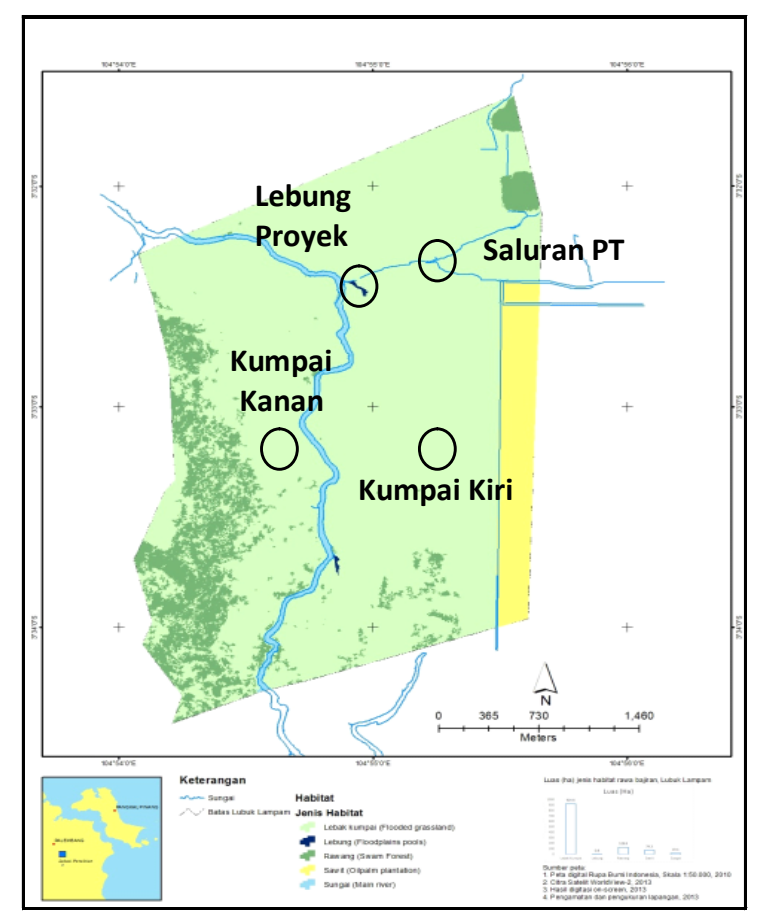

Gambar 1. Peta Lubuk Lampam dan lokasi penelitian.

Figure 1. Map of Lubuk Lampam flood plain and research station.

\section{Analisis Data}

\section{Sebaran Frekuensi Ukuran Ikan Betok}

Jumlah kelas ukuran panjang ikan contoh dihitung dengan menggunakan rumus Sturges (Sugiyono, 2003), yakni: $\mathrm{K}=1+(3,32 \times \log \mathrm{n}), \mathrm{K}$ adalah jumlah kelas ukuran, $\mathrm{n}$ adalah jumlah data pengamatan. Analisis hubungan panjang-berat untuk mengetahui pola pertumbuhan ikan menggunakan rumus Effendie (1979) yaitu: $\mathrm{W}=\mathrm{aL}^{\mathrm{b}}$ dimana $\mathrm{W}$ adalah berat ikan (gram); L adalah panjang total ikan (mm); a dan b adalah konstanta.

\section{Nisbah Kelamin}

Nisbah kelamin diketahui berdasarkan perbandingan antara jumlah ikan jantan dan betina yang tertangkap pada setiap sampling. Jenis kelamin ditentukan setelah sampel ikan tersebut dibedah. Nisbah kelamin dianalisis menurut Effendie (2002) sebagai berikut:

$$
\mathrm{Nk}=\frac{\mathrm{M}}{\mathrm{F}}
$$

Keterangan :

$\mathrm{N}_{\mathrm{k}}=$ nisbah kelamin

$\mathrm{M}=$ jumlah total ikan jantan (ekor)

$\mathrm{F}=$ jumlah total ikan betina (ekor)

Untuk melihat keragaman jenis kelamin digunakan uji "Chi-Square" (Steel \&Torrie, 1993). 


\section{Tingkat Kematangan Gonad}

Tingkat Kematangan Gonad (TKG) ikan jantan dan betina ditentukan secara morfologi mencakup warna, bentuk, dan ukuran gonad. Perkembangan gonad secara kualitatif ditentukan dengan mengamati TKG I-V berdasarkan morfologi gonad, mengikuti klasifikasi Effendie (1979).

\section{Indeks Kematangan Gonad}

Indeks kematangan gonad (IKG) diukur dari perbandingan bobot tubuh dengan berat gonad ikan jantan dan betina menggunakan timbangan yang mempunyai ketelitian 0,01 gram. Indeks kematangan gonad dihitung dengan rumus sebagai berikut (Effendie, 1979):

Keterangan :

$$
\operatorname{IKG}(\%)=(\mathrm{Bg}: \mathrm{Bt}) \times 100
$$

$\mathrm{IKG}=$ indeks kematangan gonad

$\mathrm{B}_{\mathrm{g}}=$ berat gonad (gram)

$\mathrm{B}_{\mathrm{t}}^{\mathrm{g}}=$ berat tubuh $($ gram $)$

\section{Ukuran Pertama Kali Matang Gonad}

Pendugaan ukuran pertama kali matang gonad dengan menggunakan metode Sperman Karber (King, 1995). Kriteria matang gonad adalah pada TKG III, IV, dan V.

$$
\mathrm{Pi}=\mathrm{ri} / \mathrm{ni} \log M=X_{k}+\frac{\bar{x}}{2}-\left(\bar{x} \sum P i\right)
$$

Keterangan:

$\mathrm{X}_{\mathrm{k}}=$ logaritma nilai tengah pada saat ikan matang gonad $100 \%$

$=$ rata-rata selisih logaritme nilai tengah

ri $=$ jumlah ikan matang gonad pada kelas ke-i

$\overline{\mathrm{Ax}}=$ jumlah ikan total

\section{Fekunditas dan Potensi Reproduksi}

Fekunditas dihitung dengan metode gravimetrik (Effendie, 1979):

$$
\mathbf{F}=\frac{G}{Q} \times \mathbf{N}
$$

dimana :

$F=$ fekunditas (butir)

$G=$ berat $\operatorname{gonad}(\mathrm{g})$

$Q=$ berat gonad contoh $(\mathrm{g})$

$N=$ jumlah telur tiap gonad contoh

Berat gonad ikan diukur dengan cara membedah ikan contoh yang telah diawetkan, gonadnya diambil untuk kemudian ditimbang dengan timbangan eletronik dengan ketelitian 0,0001 mg. Berat gonad contoh diambil dengan cara memotong sebagian gonad pada bagian anterior, tengah dan posterior gonad untuk kemudian ditimbang. Jumlah telur pada gonad contoh dihitung di bawah mikroskop yang dilengkapi micrometer dengan pembesaran 10x4 kali. Potensi reproduksi diduga dari nilai fekunditas yang diasumsikan sebagai jumlah telur yang terdapat dalam ovari ikan yang telah mencapai TKG IV.

\section{Pola Reproduksi}

Pola reproduksi diduga dari besar diameter dan pola sebaran telur. Pola sebaran diameter telur dianalisis secara diskriptif dengan melihat modus penyebarannya. Apabila terlihat dua modus penyebaran, pola pemijahannya berlangsung dalam waktu yang panjang atau telur yang dikeluarkan sebagian-sebagian (partial spawning). Jika terdapat penyebaran ukuran diameter telur dalam satu modus, pola pemijahan berlangsung dalam waktu yang singkat (total spawning).

\section{HASIL DAN BAHASAN}

\section{HASIL}

\section{Sebaran Frekuensi Ukuran Ikan Betok}

Jumlah ikan betok yang diperoleh selama penelitian sebanyak 540 ekor, yang terdiri dari 187 ekor ikan jantan dan 353 ekor ikan betina. Hasil analisis menunjukkan ada 9 kelas ukuran panjang total pada ikan betina dengan kisaran antara 27-224 mm, dan 9 kelas ukuran panjang total ikan jantan dengan kisaran panjang antara 48-243 mm. Frekuensi ukuran panjang ikan betina terbanyak berada pada selang kelas ukuran 119-141 mm, yaitu sebanyak 175 ekor sedangkan frekuensi ukuran panjang ikan jantan terbanyak berada pada selang kelas ukuran 124-142 mm, yakni sebanyak 88 ekor (Tabel. 1).

Hubungan panjang berat ikan betok jantan mengikuti persamaan $\mathrm{W}=0.00004 \mathrm{~L}^{2,849}$ dengan nilai b sebesar 2,849, sedangkan ikan betok betina mengikuti persamaan $\mathrm{W}=$ $0,000 \mathrm{~L}^{2,622}$ dengan nilai b sebesar 2,622. Nilai koefisien korelasi (r) pada persamaan hubungan panjang-berat tersebut cukup tinggi, baik pada ikan betok jantan $(0,9715)$ maupun betina $(0,9110)$ (Gambar. 2). Berdasarkan hasil uji $\mathrm{t}$ diperoleh bahwa pola pertumbuhan ikan betok jantan maupun betina adalah alometrik negatif, yaitu pertambahan nilai panjang tubuh ikan lebih cepat daripada pertumbuhan nilai berat tubuhnya.

\section{Nisbah Kelamin}

Ikan betok yang diperoleh selama penelitian berjumlah 540 ekor terdiri dari 187 ekor ikan jantan dan 353 ekor ikan betina dengan rasio kelamin $0,53: 1$. Berdasarkan waktu pengambilan contoh setiap bulannya, nilai rasio kelamin 
Tabel 1. Jumlah ikan menurut selang kelas tertinggi dari kisaran panjang tertinggi ikan betok

Table 1. Total numbers by range of total length of climbing perch

\begin{tabular}{cccc}
\hline \multirow{2}{*}{ Jumlah/Total } & Jumlah/Total $(\mathbf{m m})$ \\
Jantan/Male & Betina/Female & Jantan/Male & Betina/Female \\
\hline 4 & 1 & $48-66$ & $27-49$ \\
0 & 7 & $67-85$ & $50-72$ \\
14 & 20 & $86-104$ & $73-95$ \\
60 & 55 & $105-123$ & $96-118$ \\
88 & 175 & $124-142$ & $119-141$ \\
18 & 77 & $143-161$ & $142-164$ \\
2 & 14 & $162-180$ & $165-187$ \\
0 & 3 & $181-199$ & $188-210$ \\
1 & 1 & $200-218$ & $211-233$ \\
\hline
\end{tabular}

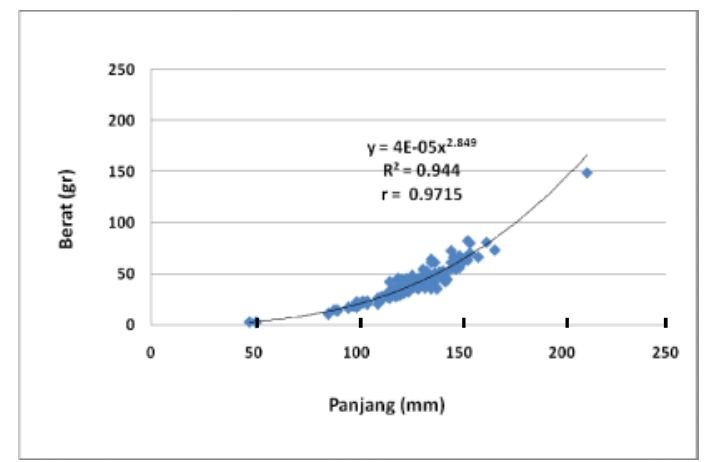

a

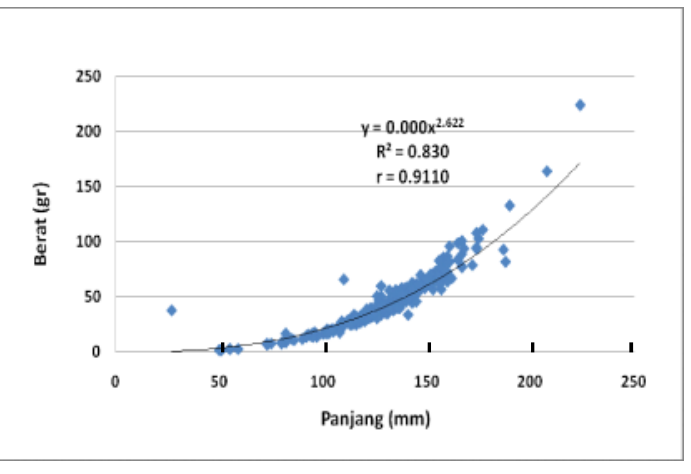

$\mathrm{b}$

Gambar 2. Hubungan panjang berat ikan betok (Anabas testudineus) (a) jantan, (b) betina.

Figure 2. Length-weigth relationship of climbing perch (Anabas testudineus) (a) male, (b) female.

berkisar antara 0,24-1,75. Rasio kelamin tertinggi diperoleh pada bulan Januari 2013 yaitu sebesar 1,75, dan rasio kelamin terendah dengan nilai 0,24 pada bulan Maret 2013 (Lampiran. 1). Berdasarkan uji Chi-square terhadap nisbah kelamin secara keseluruhan pada taraf nyata 0,05 diperoleh $\div 2$ hitung $>\div^{2}$ tabel $(51>3,8410)$ yang berarti nisbah kelamin ikan betok selama penelitian tidak sama.

\section{Tingkat dan Indeks Kematangan Gonad}

Secara umum frekuensi ukuran panjang tertinggi antara ikan jantan dan betina hampir sama kecuali pada TKG III dimana jantan (127-137 mm) dan betina (140-158 mm). Frekuensi tertinggi ukuran panjang ikan betok jantan dan betina berdasarkan tingkat kematangan gonad dapat dilihat pada Lampiran 2. Sedangkan persentase tingkat kematangan gonad ikan betok setiap bulan berdasarkan tinggi muka air dan curah hujan dapat dilhat pada Lampiran. 3. Kisaran indek kematangan gonad (IKG) pada TKG IV ikan jantan berkisar 1,3-15,0\% dengan rata-rata 5,15 $\pm 0,89$ $\%$ sedangkan pada ikan betok betina berkisar $1,2-17,1 \%$ dengan rata-rata $4,04 \pm 0,77 \%$.

\section{Ukuran Panjang Ikan Pertama Kali Matang Gonad}

Berdasarkan hasil analisis pendugaan ukuran pertama kali ikan matang gonad dengan metode Spearmen-Karber maka panjang tubuh ikan betok betina terkecil mencapai matang gonad (TKG IV) adalah $160 \mathrm{~mm}$ sedangkan ikan betok jantan pada panjang $177 \mathrm{~mm}$. Ukuran panjang tubuh ikan betok jantan dan betina pertama kali matang gonad (Lm) berturut-turut adalah $177 \mathrm{~mm}$ dan $160 \mathrm{~mm}$ (Lampiran. 4). Hal ini menunjukkan bahwa ikan betok betina lebih cepat matang gonad dari pada ikan jantan.

\section{Fekunditas dan Potensi Reproduksi}

Fekunditas ikan betok diperoleh berdasarkan analisis 38 sampel gonad yang sudah masak yakni TKG III (10 gonad) dan TKG IV (28 gonad). Jumlah telur ikan betok berkisar antara 224-182.736 butir dengan rata-rata 11.862 \pm 5.219 butir. Ini berarti potensi reproduksi ikan betok berkisar antara 224-182.736 butir. Jumlah telur ikan betok terendah ditemukan pada ikan dengan panjang total tubuh $133 \mathrm{~mm}$ sebanyak 224 butir telur (TKG IV), sedangkan 
Tabel 2. Jumlah sampel dan kisaran diameter telur ikan betok

Table 2. Number of sample and egg diameter of climbing perch

\begin{tabular}{lcccccc}
\hline \multicolumn{1}{c}{ Parameter/ } & \multicolumn{6}{c}{ Bulan/Month } \\
\multicolumn{1}{c}{ Parameter } & Nop 2012 & Des 2012 & Apr 2013 & Jul 2013 & Ags 2013 & Sep 2013 \\
\hline Jumlah sampel & 150 & 144 & 87 & 177 & 315 & 720 \\
Diamater & $0,350-0,80$ & $0,575-2,125$ & $0,629-1,04$ & $0,464-0,998$ & $0,407-1,075$ & $0,376-0,975$ \\
\hline
\end{tabular}

jumlah telur tertinggi ditemukan pada ikan dengan panjang total tubuh $190 \mathrm{~mm}$ sebanyak 182.736 butir pada TKG IV. Fekunditas dapat dihubungkan dengan panjang maupun berat ikan. Berikut ini adalah grafik hubungan fekunditas dengan panjang dan fekunditas dengan berat (Lampiran. 5). Secara eksponensial hubungan fekunditas dengan panjang dirumuskan $\mathrm{F}=0,0000002 \mathrm{~L}^{4,636}$ dengan koefiesien korelasi 0,46 yang artinya hanya $46 \%$ dapat dijelaskan panjang terhadap fekunditas dan hubungan fekunditas dengan berat dirumuskan $\mathrm{F}=2,846 \mathrm{~W}^{1,663}$ dengan koefisien korelasi 0,41 yang artinya hanya $41 \%$ yang dapat menjelaskan berat terhadap fekunditas. Nilai $r$ yang kurang dari 0,5 menunjukkan bahwa hubungan antara kedua variabel tersebut korelasinya rendah.

\section{Pola Reproduksi}

Diameter telur ikan betok diamati pada bulan Nopember 2012, Desember 2012, April 2013, Juli 2013, Agustus 2013 dan September 2013. Jumlah sampel dan ukuran diameter telur dapat dilihat pada Tabel. 2 .

Sebaran diameter telur ikan betok pada TKG III dan IV setiap bulannya menunjukkan dua kelompok (modus) (Lampiran. 6). Hal ini menunjukkan bahwa telur ikan betok tidak matang secara serentak. Patut diduga ikan betok melakukan dua kali pemijahan dalam setahun dan termasuk ikan yang memijah secara sebagian (partial spawner).

\section{BAHASAN}

Ikan betok (Anabas testudineus) merupakan salah satu ikan air tawar yang penyebarannya cukup luas di Indonesia. Ikan ini memiliki daya adaptasi yang cukup baik terhadap berbagai tipe ekosistem perairan umum terutama di paparan banjir seperti rawa, sungai, danau dan sawah (Diana et al., 1985), sehingga menjadikannya sebagai salah satu ikan yang dominan di paparan banjiran. Nilai koefisien korelasi (r) persamaan hubungan panjangberat cukup tinggi, menunjukkan hubungan yang erat antara panjang dan berat ikan betok. Artinya pertambahan panjang total ikan akan diikuti oleh pertambahan berat dengan pola pertumbuhan alometrik negatif.

Nisbah kelamin merupakan proporsi antara ikan jantan dan betina. Di alam perbandingan antara jantan dan betina biasanya 1:1 (Jacob, 2005). Nisbah kelamin ikan betok mengalami fluktuasi setiap bulannya, sedangkan perbandingan secara keseluruhan jumlah ikan jantan lebih sedikit dari ikan betina $(0,57: 1)$. Rata-rata setiap bulan, perbandingan ikan jantan dan betina dalam kondisi tidak sama, kecuali pada bulan Januari dimana jumlah ikan jantan lebih banyak dari betina. Hasil penelitian Jacob (2005) diperoleh nisbah kelamin ikan betok 0.94 sedangkan hasil penelitian Chanchalt et al. (1978) sebesar 1,5. Nilai nisbah kelamin yang diperoleh selama penelitian sama dengan Jacob (2005) dimana ikan jantan lebih sedikit dari ikan betina, namun berbeda dengan yang dilaporkan oleh Chanchalt et al. (1978). Hal ini diduga karena perbedaaan tingkah laku antara ikan jantan dan betina yang cenderung bersembunyi dan bermigrasi saat melakukan pemijahan (Jacob, 2005). Menurut Zworykin (2012) bahwa sistem perkawinan ikan betok bersifat poligami atau percampuran, dimana jantan akan membuahi betina lebih dari satu. Dengan demikian pada saat musim pemijahan jumlah ikan jantan yang tertangkap biasanya lebih sedikit dari betina.

Tingkat kematangan gonad ikan betok mengalami perubahan setiap bulannya. Tingkat kematangan gonad (TKG) III dan IV pada ikan dewasa ditemukan pada bulan Nopember, Desember, Januari, April dan Juli. Pada bulan Nopember ikan betina yang tertangkap seluruhnya memiliki TKG IV sedangkan bulan Desember perbandingan TKG III dan IV sebesar 48\%: 52\%. Untuk ikan jantan perbandingan TKG III dan IV pada bulan Nopember sebesar 13\% : 87\% dan Desember sebesar 50\% : 50\%. Selanjutnya pada bulan Januari, Februari, Maret dan Juni sebagian besar ikan ditemukan memiliki TKG I dan II sedangkan pada bulan April, Juni, Agustus, September dan Oktober ditemukan pula ikan jantan dan betina yang telah matang gonad (TKG III dan IV). Berdasarkan pengamatan selama penelitian patut diduga bahwa pemijahan ikan betok dipengaruhi oleh fluktuasi tinggi muka air. Banyak literatur yang menyatakan bahwa pemijahan ikan betok berlangsung hanya pada musim penghujan (ketika banjir). Hasil penelitian Jacob (2005); Thakur (2004) bahwa pemijahan ikan betok di India berlangsung pada bulan Mei-Juni. Perbedaan musim pemijahan ini diduga karena perbedaan hydrografi lokasi. Weber (1974) menyatakan musim pemijahan ikan tropis berhubungan erat dengan faktor hydrografi suatu wilayah.

Ikan betina dengan TKG III dan IV yang ditemukan pada bulan Juli-Oktober ini merupakan hal yang aneh karena hampir sebagian literatur menyatakan bahwa ikanikan paparan banjiran termasuk betok memijah pada awal musim penghujan. Hal ini diperkuat hasil penelitian Zworykin (2012) bahwa ikan betok memijah pada malam 
hari di air yang keruh dan berlangsung di musim penghujan. Adanya fenomena ini diduga karena pada bulan tersebut wilayah Indonesia terkena dampak Indian Ocean Dipole (IOD) negatif (Antara news, 2013) yang menyebabkan musim kemarau diselingi dengan hujan sehingga fenomena ini dikenal dengan musim kemarau yang basah. Fenomena ini menyebabkan muka air di Lubuk Lampam mengalami fluktuasi dan banjir sepanjang tahun sehingga kondisi ini menjadikan pemicu bagi ikan betok untuk memijah.

Indek kematangan gonad ikan betina yang ditemukan selama penelitian berkisar 1,2 -17,1\% dengan rata-rata 4,04 $\pm 0,77 \%$. Nilai ini cukup rendah dibandingkan dengan hasil penelitian yang dilakukan oleh Amornsakun et al., (2004), dimana IKG ikan betok (Anabas testudineus) 10,4\% sedangkan hasil penelitian Jacob (2005) diperoleh nilai IKG berkisar 2,95-9,84\% dengan nilai tertinggi sebesar 14\%. Hasil penelitian yang dilakukan oleh Shashi \& Akela (1996) di India bagian Utara diperoleh nilai IKG ikan betok sebesar 9,6-15,5\%. Selanjutnya menurut Amornsakun et al. (2004) untuk ikan-ikan air tawar lainnya nilai IKG berkisar antara 8-10\%. Berdasarkan data tersebut maka rata-rata ukuran gonad ikan betok di Lubuk Lampam hampir sama dengan yang ditemukan di daerah lainnya. Menurut Sumpter (1990) siklus reproduksi setiap jenis ikan telah berkembang untuk merespon setiap perubahan habitat alaminya. Waktu pemijahan ikan setiap tahunnya berkembang sebagai respon terhadap faktor utama yang akan memaksimalkan kelangsungan hidup telur dan larva. Beberapa faktor utama antara lain kualitas air, ketersediaan makanan dan penurunan jumlah predator.

Dilihat dari ukuran pertama kali matang gonad, ikan betok betina $(160 \mathrm{~mm})$ lebih cepat matang gonad daripada ikan jantan $(177 \mathrm{~mm})$. Ukuran ikan betina yang matang gonad lebih besar dibandingkan yang ditemukan Chanchal et al. (1978) dan Pillay (1962) dalam Jacob (2005) dan Jacob (2005) masing-masing $82 \mathrm{~mm}, 80 \mathrm{~mm}$ dan $91 \mathrm{~mm}$. Ini menunjukkan bahwa eksploitasi atau tekanan penangkapan yang dilakukan diperairan Lubuk Lampam masih kecil. Cepat atau lambatnya ikan betina matang gonad diduga berkaitan erat dengan tingkat eksploitasi atau penangkapan di suatu tempat. Tekanan penangkapan yang tinggi akan mempengaruhi dan merubah tingkah laku pemijahan ikan betina. Nasution (2008) menyatakan bahwa ukuran ikan pertama kali matang gonad memiliki hubungan dengan pertumbuhan ikan. Faktor lingkungan berpengaruh terhadap pertumbuhan serta strategi reproduksinya. Selain itu, menurut Craig et al. (2004) bahwa ukuran ikan pertama kali matang gonad biasanya lebih cepat pada ikan betina dari pada ikan jantan. Selanjutnya Mustakim (2008) juga menegaskan bahwa perbedaan ukuran pertama kali matang gonad bisa terjadi pada suatu spesies ikan yang memiliki jenis kelamin yang berbeda.
Adapun perbedaan ukuran pertama kali matang gonad pada ikan betok diduga dipengaruhi oleh kelimpahan, kondisi lingkungan, ketersediaan makanan dan tekanan penangkapan. Menurut Senen et al. (2009) dalam Dewanti et al. (2012) bahwa ukuran pertama kali matang gonad pada ikan berbeda-beda, bahkan spesies yang sama namun berbeda habitatnya matang gonadnya bisa ditemukan pada ukuran yang berbeda pula. Ukuran pertama kali matang gonad bisa dipengaruhi faktor lingkungan. Ikan yang mengalami tekanan karena penangkapan yang tinggi, cenderung matang gonad pada ukuran lebih kecil.

Fekunditas ikan betok berkisar 224-182.736 butir dengan rata-rata $11.862 \pm 5.219$ butir. Jacob (2005) menyatakan bahwa fekunditas ikan betok berkisar 1.00059.022 butir. Hasil analisis hubungan fekunditas dengan panjang total dan fekunditas dengan berat menunjukkan korelasi atau hubungan yang rendah sehingga perbedaan fekunditas yang terjadi diduga lebih disebabkan oleh faktor lingkungan dan tingkah laku pemijahan. Hubungan antara fekunditas dengan panjang total dan berat yang rendah juga terjadi pada ikan betok di perairan Malaysia (Marimuthu et al., 2009).

Menurut Taylor \& Francis (2009) selain ketersediaan makanan faktor lingkungan yang berpengaruh terhadap reproduksi ikan adalah lama pencahayaan, suhu, curah hujan, arus dan tekanan air. Selama penelitian curah hujan tahun 2013 cukup tinggi sekitar $3.406 \mathrm{~mm}$ sedangkan tahun 2012 hanya $2.289 \mathrm{~mm}$, sehingga selama tahun 2013 di lokasi penelitian masih digenangi air. Selain itu, Nikolsky (1969) dalam Effendie (2002) mengemukakan bahwa variasi fekunditas disebabkan oleh adanya kelompok ikan yang baru memijah dan sudah memijah, sehingga produksi telur cenderung lebih tinggi daripada ikan yang baru memijah, akibatnya penyebaran produksi telur yang tidak merata. Ikan muda memiliki fekunditas relatif lebih banyak dibandingkan ikan tua atau yang sudah pernah memijah. Berdasarkan Adilaviana (2012) pada setiap bulan pengamatan memiliki lebih dari satu kelompok ukuran, dan pada setiap kelompok ukuran tersebut didapati ikan yang matang gonad sehingga fekunditas dapat bervariasi.

Ukuran diameter telur ikan betok yang diperoleh setiap bulannya bervariasi. Kisaran ukuran diamater telur yang ditemukan selama penelitian secara keseluruhan hampir sama dengan yang ditemukan Jacob (2005) dan Mazumdar (1946) dalam Jacob (2005) dimana diameter telur berkisar 0,61-1,2 mm dan Patowary \& Dutta (2012) berkisar 0,56$0,80 \mathrm{~mm}$. Namun pada bulan Desember 2012 kisaran telur ikan betok agak berbeda dan sebagian memiliki ukuran diameter lebih besar (>1,2 mm). Perbedaan ini disebabkan karena faktor genetik dan populasi (Tyler \& Sumpter, 1990 dalam Jacob, 2005). Berdasarkan sebaran ukuran diameter 
telur pola reproduksi ikan betok termasuk pemijahan secara sebagian (partial spawner), dimana telur dikeluarkan tidak secara serempak. Pola pemijahan ikan betok di Lubuk Lampam berbeda dengan yang dilaporkan Yacob (2005) dimana ikan betok memijah satu kali dalam setahun. Perbedaan ini diduga karena dipengaruhi oleh faktor hidrologi terutama fluktuasi muka air karena tahun 2013 perairan Lubuk Lampam terkena dampak Indian Ocean Dipole (IOD) negatif yang menyebabkan fluktuasi muka air yang lebih intens dan banjir terjadi hampir sepanjang tahun. Wootton (1998) dalam Ballesteros et al. (2009) menyatakan pola pemijahan ikan di daerah beriklim sedang sebagian besar dipengaruhi oleh suhu sedangkan di daerah tropis dipengaruhi oleh sistem hidrologi.

\section{KESIMPULAN}

Ikan betok mempunyai pola pertumbuhan alometrik negatif, dimana pertambahan panjang lebih cepat dari pada berat tubuhnya. Nisbah kelamin antara jantan dan betina tidak sama kecuali pada bulan Januari. Ikan betok betina relatif lebih cepat matang gonad dari pada ikan jantan. Fekunditas ikan betok bervariasi antara 224-182.736 butir dengan rata-rata $11.862 \pm 5.219$ butir. Ikan betok memiliki pola pemijahan secara serempak (total spawner).

\section{SARAN}

Dalam upaya menjaga kelestarian sumberdaya ikan betok dimasa mendatang perlu diperhatikan waktu penangkapan ikan betok. Penangkapan ikan betok jangan dilakukan selama musim penghujan karena saat tersebut merupakan musim pemijahan.

\section{DAFTAR PUSTAKA}

Adilaviana, T. 2012. Kajian stok ikan swanggi (Priacanthus tayenus) yang didaratkan di PPP Labuan Banten. Skripsi. Departemen Manajemen Sumberdaya Perairan, Fakultas Perikanan dan Ilmu Kelautan, Institut Pertanian Bogor. Bogor: 70 hlm. (Tidak Diterbitkan)

Akbar, J. 2012. Pertumbuhan dan kelangsungan hidup ikan betok (Anabas testudineus) yang dipelihara pada salinitas berbeda. Bioscientiae, 9 (2): 1-8.

Amornsakun, T., W. Sriwatana \& P. Promkaew. 2004. Some aspects in early life stage of Siamese gourami, Trichogaster pectoralis (Regan) Larvae. Songklanakarin Journal Science Technology. 26 (3): 347-356.

Antaranews. 2013. Kemarau basah diperkirakan terjadi mulai Juni. www.antaranews.com.
Bungas, K., D. Arfiati, Marsoedi \& H. Halim. 2013. Effects of protein levels on the growth of Climbing perch, Anabas testudineus Galam type, in Peat Water. International Research Journal of Biological Science. 2(4): 55-58.

Chanchal, A. K., R.N. Pandey \& S.B. Singh, S. B. 1978. Studies on some aspects of the biology of Anabas testudineus (Teleostei: Anabantidae). Matsya, 4: 1519.

Craig, J.F., A.S. Halls , J.J.F. Barr, C.W. Bean . 2004. The Bangladesh floodplain fisheries. Fisheries Research 66. Pp 271-286. www.elsevier.com/locate/fisher. [Desember 2009].

Dewanti, Y. R, Irwani \& S. Rejeki. 2012. Studi reproduksi dan morfometri ikan sembilang (Plotosus canius) betina yang didaratkan di pengepul wilayah Krobokan Semarang. Journal of Marine Research, 1(2): 135.144.

Diana, J.S., W.Y.B. Chang, D. R. Ottey \& W. Chuapoehuk. 1985. Production systems for commonly culture freshwater fishes of Southeast Asia. International Programs Report No. 7 Great Lakes and Marine Waters Center The University of Michigan. $126 \mathrm{p}$.

Effendie MI. 2002. Biologi perikanan. Yayasan Pustaka Nusatama. Yogyakarta: $163 \mathrm{hlm}$.

Effendie MI. 1979. Metoda Biologi Perikanan. Yayasan Dewi Sri, Bogor : 112 hal.

Ernawati, Y; M. M. Kamal \& A. Y. Pellokila. 2009. Biologi reproduksi ikan betok (Anabas testudineus Bloch, 1792) di Rawa Banjiran Sungai Mahakam, Kalimantan Timur. Jurnal Iktiologi Indonesia 9(2):113-127.

Jacob. P. K. 2005. Studies on Some Aspects of Reproduction of Female Anabas Testudineus (Bloch). Thesis. Departemen of Marine Biology, Microbiology and Biology. Cochin University of Science and Technology India: 261pp

Khan, H.A; B. B. Ghosh \& S. K. Mukhopadhyay. 1976. Observations on the salinity tolerance of Anabas testudineus (Bloch) Central. Inl. Fish. Res. Inst., Barrackpore, West-Bengal, India. J. Inland. Fish. Soc. India, $8: 111-112$.

King, M. 1995. Fisheries Biology. Assesment and Management. Fishing News Books, Blackwell Science Ltd. 
Marimuthu, K. J. Arumugam, D. Sandragasan \& R Jegathambigai. 2009. Studies on the fecundity of Native Fish Climbing Perch (Anabas Testudineus, Bloch) in Malaysia, Am.-Eurasian J. Sustain. Agric., 3 (3): 266-274.

Murjani, A. 2011. Performansi pertumbuhan beberapa varietas ikan betok (Anabas testudineus $\mathrm{BLOCH}$ ) yang dipelihara di perairan rawa. Chlorophyl 7(2): 345-350.

Mustakim, M. 2008. Kajian Kebiasaan Makan dan Kaitannya dengan Aspek Reproduksi ikan Betok (Anabas testudineus Bloch) pada Habitat yang Berbeda di Lingkungan Danau Melintang Kutai Kartanegara Kalimantan Timur. Tesis. SPS IPB. Bogor.

Nasution, S.H. 2008. Ekobiologi dan Dinamika Stok Sebagai Dasar Pengelolaan Ikan Endemik Bonti-Bonti (Paratherina Striata Aurich) Di Danau Towuti, Sulawesi Selatan. Disertasi. Sekolah Pascasarjana Institut Pertanian Bogor. 73 hal.

Patowary, R.K \& A. Dutta. 2012. Breeding performance of Anabas testudineus (Bloch) in specially designed cemented tanks. Asian J. Exp. Biology Science 3(4): 762-766.

Shashi, S. B. and B. P. Akela, 1996. Determination of maturity and spawning period by gonadosomatic index and measurement of mean ova diameter in certain teleosts. Environ. Eeol., 14 (2): 399-403.

Shinsuke, M., Sayaka, I., Shoji.K., \& Bounsong, V. 2009. Growth and morphological development of laboratory reared larval and juvenile climbing perch Anabas testudenius. The Ichtyological Society of Japan. J. Ichthyol Res 56: 162-171.
Steel, R. G. D \& J. H. Torrie. 1993. Prinsip dan Prosedur Statistik. Terjemahan Bambang Sumantri. PT. Gramedia. Jakarta. 748 p.

Sugiyono, 2003. Statistika Untuk Penelitian. CV Alfabeta. Bandung.

Sumpter, J. P. 1990. General concepts of seasonal reproduction. In: Reproductive seasonality in Teleosts: Environmental influences (Munro, A. D., A. P. Scott. and T. J. Lam eds.) CRC Press, Boca Raton, F. L. 13 hal.

Taylor \& Francis. 2009. Methods in reproductive aquaculture marine and freshwater species. CRC Press: New York, Suite 300.

Thakur, D. P. 2004. New Fish Spesies Studied for Aquaculture Potential by Aquaculture CRSP Researchers. Aquanews 19(1): 1\&6.

Walpole RE, 1995. Pengantar Statistika edisi Ke-3 alih Bahasa oleh Sumantri, B. PT Gramedia Pustaka Utama, Jakarta.

Weber, W., 1974. The influence of hydrographical factors on the spawning time of tropical fish. Proc. Int. Seminar. Fish. Res. and their Management in S. E. Asia: 269-281.

Zworykin, D.D. 2012. Reproduction and spawning behaviour of the climbing perch Anabas testudineus (Perciformes, Anabantidae) in an aquarium. Journal of Ichthyology 52(6): 379-388. 
Lampiran 1. Nisbah kelamin ikan betok

Annex 1. Sex ratio of climbing perch

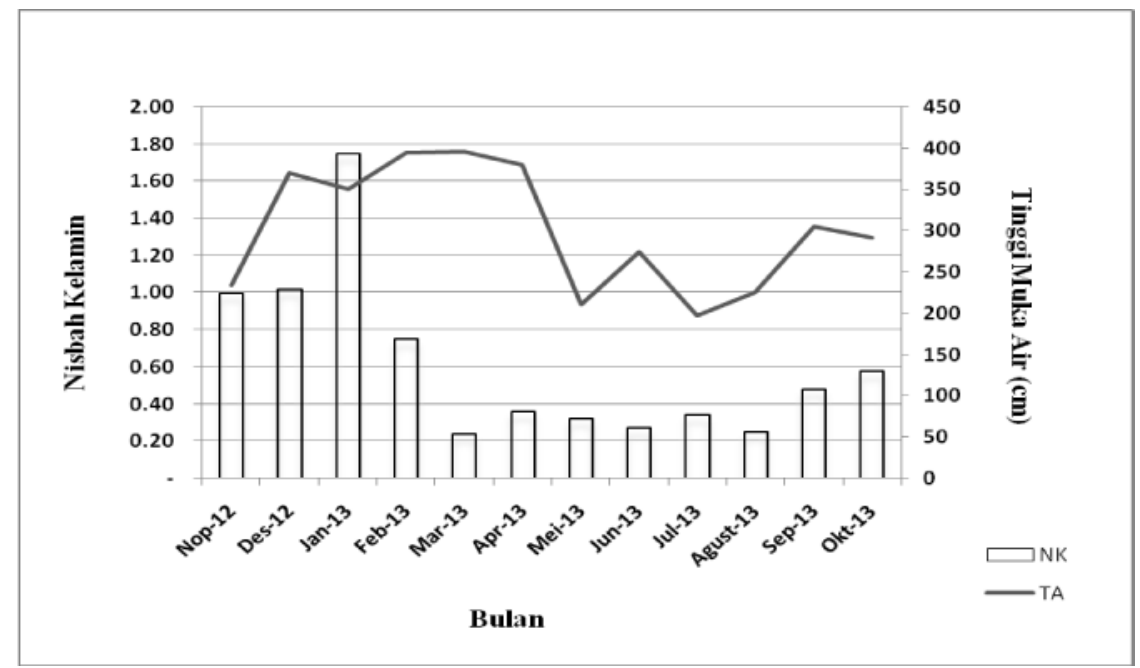

Keterangan/: $\mathrm{NK}=$ Nisbah kelamin
Remark TA $=$ Tinggi muka air

Lampiran 2. Frekuensi ukuran panjang ikan betok jantan dan betina berdasarkan tingkat kematangan gonad Annex 2. Lenght frequency of climbing perch based on the level of gonado maturity

\begin{tabular}{|c|c|c|c|c|c|c|}
\hline \multirow{2}{*}{$\begin{array}{l}\text { Tingkat Kematangan } \\
\text { Gonad/Gonad maturity state }\end{array}$} & \multicolumn{2}{|c|}{$\begin{array}{c}\text { Selang Kelas Ukuran/Size } \\
\text { Interval }\end{array}$} & \multicolumn{2}{|c|}{$\begin{array}{c}\text { Frekuensi Tertinggi }(\mathrm{mm}) / \text { Highest } \\
\text { frequency }\end{array}$} & \multicolumn{2}{|c|}{ Jumlah/Total } \\
\hline & Jantan/Male & Betina/Female & Jantan/Male & Betina/Female & Jantan/Male & Betina/Female \\
\hline I & 7 & 8 & $116-132$ & $114-129$ & 34 & 33 \\
\hline II & 6 & 8 & $129-152$ & $132-152$ & 22 & 63 \\
\hline III & 6 & 6 & $127-137$ & $140-158$ & 8 & 11 \\
\hline IV & 7 & 7 & $124-142$ & $128-148$ & 22 & 38 \\
\hline
\end{tabular}

Lampiran 3. Persentase tingkat kematangan gonad ikan jantan (a) dan betina (b) berdasarkan tinggi muka air dan curah hujan.

Annex 3. Percentage of the level of gonado maturity, male (a) and female (b) based of water level and rainfall.
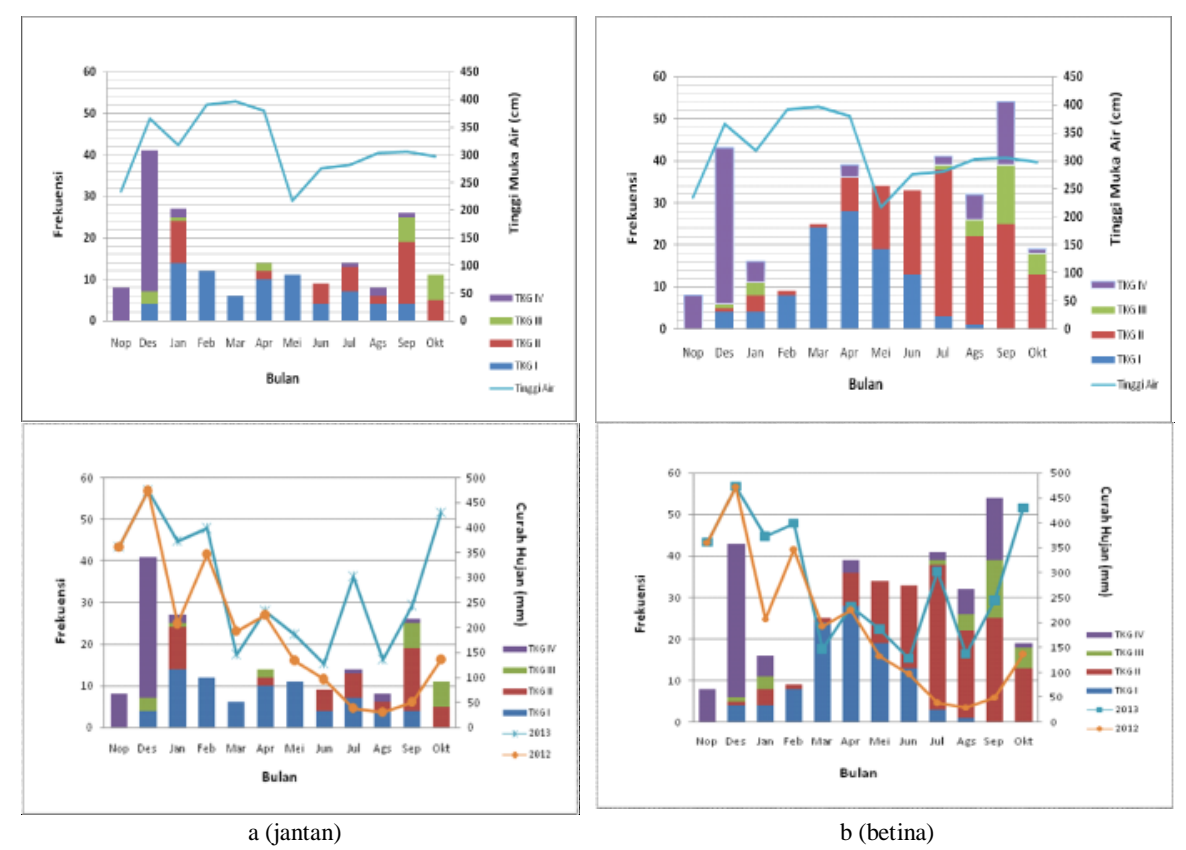
Lampiran 4. Ukuran panjang ikan betok (A. testudineus) jantan dan betina pertama kali matang gonad (Lm) Annex 4. Lenght of climbing perch (A. testudineus), male and female at first maturity (Lm)

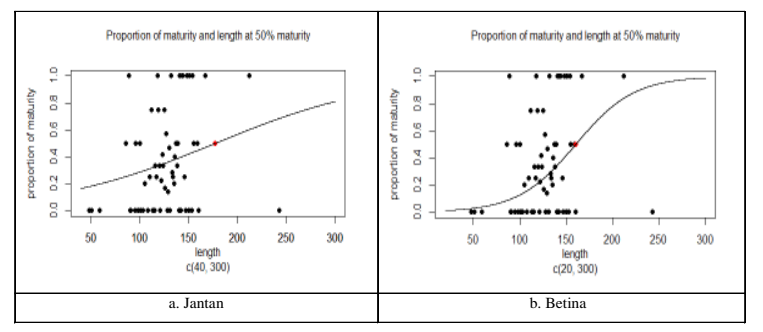

Lampiran 5. Hubungan panjang-berat dengan fekunditas ikan betok

Annex 5. Lenght-weight relationship with fecundity of climbing perch
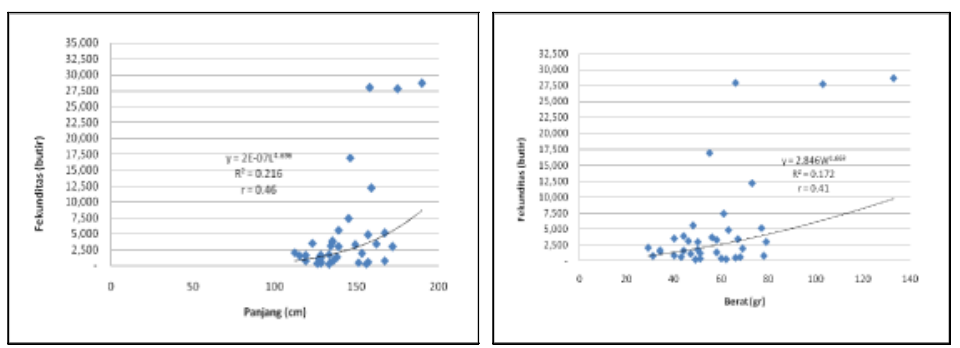

Lampiran 6. Distribusi ukuran diameter telur ikan betok

Annex 6. Egg diameter distribution of climbing perch

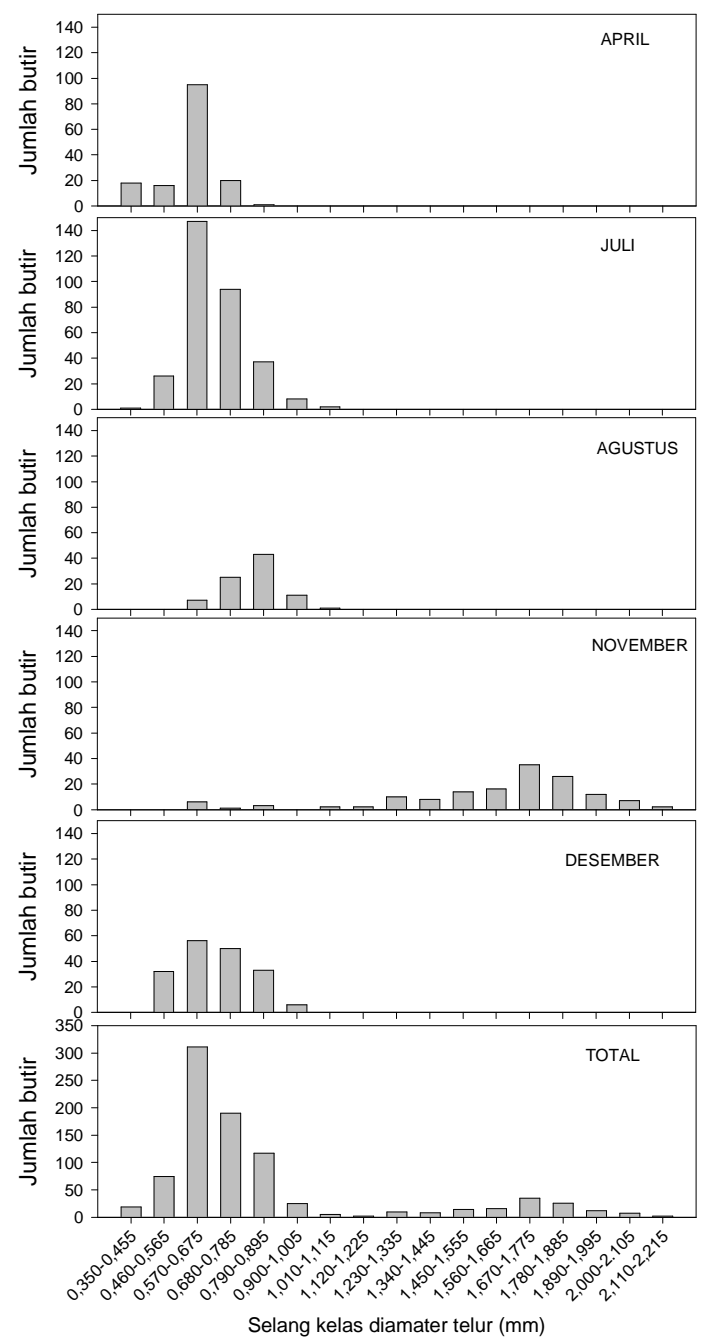

